\title{
Human Rights and Justice: Youth Perceptions in Dialogue with Public Policies in Brazil
}

\author{
Ana Maria Eyng1, Thais Pacievitch ${ }^{2,3}$, Maria de Lourdes do Prado Krüger D'Almeida4 \\ ${ }^{1}$ Program of Graduate Studies in Education, University of Paraná-PUCPR, Curitiba, Brazil \\ ${ }^{2}$ Federal Institute of Paraná-I FPRR, Curitiba, Brazil \\ ${ }^{3}$ Pontifical Catholic University of Paraná, Curitiba, Brazil \\ ${ }^{4}$ Municipal Education System of the Curitiba City Hall, Curitiba, Brazil \\ Email: eyng.anamaria@gmail.com, thaispacievitch@gmail.com, mariprado@sme.curitiba.pr.gov.br
}

Received 6 April 2016; accepted 31 May 2016; published 3 June 2016

Copyright (C) 2016 by authors and Scientific Research Publishing Inc.

This work is licensed under the Creative Commons Attribution International License (CC BY).

http://creativecommons.org/licenses/by/4.0/

(c) (i) Open Access

\begin{abstract}
In the text, the relationships between youth perceptions and public policies on human rights and justice, related to guarantee and the right protection to education, are problematized. The research, of qualitative character, comprises 591 interviews with students from 15 higher education courses, using the Delphi technique in the collection, organization and data analysis. From the information obtained, the perception of young students on human rights is related, with higher incidence, to the basic rights, considered natural and positive rights. Perceptions point justice as application of moral standards, ethical standards, meritocracy, and damage repair. Thus, it is possible to conclude that the results of this study challenge the school in order to seek to ensure and protect the rights and thus promote social justice, understanding that performance in these perspectives makes possible the effectuation of a social quality basic education.
\end{abstract}

\section{Keywords}

Educational Policies, Human Rights, Youth Perceptions, Intercultural Curriculum

\section{Introduction}

In this paper, we adopt the methodological understanding to link public policies to state theory, thus overcoming the procedure to link public policy to simple actions of government, centralizing the analysis on evaluations of results and the management of public resources. It starts from the assumption that the study of public policies 
implies the understanding of the existence of a theoretical, methodological, political and ideological complexity. "Thus, it is simplistic the positive thinking to understand the state as an institution governed by the law, at the service of all segments of society, but that keeps complexities involving ideological and class relations” (Boneti, 2011: p. 17).

In this sense, public policies are linked to the social project of the state as a whole and constitute themselves from demands of multiple combined forces that may originate either in social struggles, as in economic interests, but are always historically situated and conditioned. As citizens, we must be aware of the historical moment we are living in order to claim and collaborate on improving and resizing of developing policies.

Among the different areas of public policies, we emphasize social policies, in particular those relating to educational policies. In this direction Shiroma (2002: p. 9) states that "we are convinced that educational policies, even under the appearance often humanitarian and benefactor, always express contradictions of the historical moment in which they are occurring”.

Thus, also the right to education is detailed and set in a particular historical context. Such contexts are disputing scenarios in the different areas in which policies related to security and the right protection to education are formulated, implemented and evaluated. Since "the conflicts and disputes occur at all levels and in all arenas of educational apparatus involved in the formulation and implementation of policy [...] These policies arenas usually appear in the form of tensions and contradictions or discursive disputes [...]” (Ball \& Mainardes, 2011: p. 159).

The tensions and disputes are striking in speeches and texts of public policies of Brazilian education. The right to education has not been guaranteed to all, as the historical background of Brazilian education is strongly focused on stratification, rooted to the design of social and cultural domination by a minority of society. Thus, school education has served as producer and reproducer of social inequality and exclusion. Thus, next to an elite "well educated", formed in good schools, is an illiterate or semi-illiterate population who fails to enter the school system or excludes from it early (Romanelli, 1989: p. 33).

In Brazil, although the recent public and educational policies seek universal access to basic education and more students in higher education, overcoming inequality and the guarantee of the right to education are not actualized.

And, if it is considered the right to education with social quality, the way to go regarding its warranty is even longer to build a school that makes it possible. Along the way, the achievement of the social quality school requires as a condition for its existence dialogue with "a set of socioeconomic and cultural elements and dimensions that surround the way of life and the expectations of families and students in relation to education". Besides, it requires the understanding of "government policies, social and environmental projects in their political sense, aimed at the common good", is fundamental the "adequate funding"; "social recognition and appreciation of workers in education"; and further the transformation of "all physical spaces in place of meaningful learning and effective democratic experiences” (Silva, 2009: p. 223).

We cannot discuss the characteristics of a social quality school without thinking in the wider context where the school is located, and culture for it transmitted. Thus, "One of the biggest challenges in the history of education is to organize a school that at the same time is, of quality and democratic, that is, that does not offer the poor a poor education, but actually get students even socially disadvantaged, to learn” (Gomes, 2005: p. 286).

It is indisputable that the school has a fundamental role in building a democratic, just and egalitarian society, in the development of actions for the training of citizens, through practices for recognition and experience of principles of respect for human rights and justice. Dubet (2004: p. 542) states that schools propose a model of equal opportunities and access ignoring the social inequalities of students:

The model of meritocratic equal opportunities presupposes, to be fair, a school offering perfectly equal and objective, ignoring the social inequalities of the students. But all the research shows that the school treats less well the disadvantaged students: the obstacles are stiffer for the poorest, the stability of the teaching staff is lower in difficult neighborhoods, the expectation of teachers is less favorable for disadvantaged families who are more absent and less informed in orientation meetings (Dubet, 2004: p. 542).

In overcoming perpetrated and reinforced inequalities by the school system, it is important a magnified attention on the necessary eradication of exclusive curriculum practices because "what is possible to note about the curriculum is a long conservative historical trajectory, rooted in ideas and hegemonic practices with no intention or ability to dialogue with diversity” (Eyng, 2013: p. 31). 
The data systematization has as reference the studies of Bardin (2000) which support the content analysis, enabling the identification of the categories by which the answers were grouped, indicating the main features of the perceptions in study.

The reflection on the themes is subsidized in studies of Dubet (2008), Estêvão (2004, 2013), Santos (2007, 2010); Silva (2009) and documents which constitute the educational public policies.

\section{Research Methodological Path}

The relationship between the concepts conveyed in public policies and youth perceptions of human rights and justice are worked in a qualitative research. The research is part of the project entitled "Human Rights, Justice and Coexistence in Schools: Youth Perceptions and Curriculum Implications” developed by the research group of the Observatory of Violence in Schools of PUCPR. Data collection was performed by applying the Delphi 1 technique. The courses selected for the study were: Administration, Life Sciences, Social Sciences, Law, Physical Education, Mechanical Engineering, Philosophy, Physics, History, Languages, Mathematics, Education, Psychology, Social Service and Chemistry.

The subjects were included in the sample through individual manifestation at the moment of signing a free and clarified consent term. The exclusion of any subject from the research can be given, therefore, by the removal of his/her consent.

Students heard at this stage were addressed collectively, covering all students present in class on scheduled days. At the time, those students present were informed about the research and its objectives, all of them received the materials related to data collection (form with questions and consent term). The instruments were filled out individually by those who desired so, by signing the free and clarified consent. At the end all materials distributed were collected, both of which wished to participate as those who declined and delivered them in white, without any distinction between these two groups.

In this text we present the data obtained in the first phase of the Delphi technique, through application of the instrument which consists of open questions, student perceptions being analyzed on two questions: 1 . What do you understand by human rights? 2. What do you understand by justice?

PARA SUBSTITUIR... In the research phase whose data are presented here there was the participation of 591 students from $2^{\text {nd }}$ and $6^{\text {th }}$ periods of 15 undergraduation courses offered by a university in the city of Curitiba.

Nesse texto apresentamos os dados obtidos na primeira fase da técnica Delphi, mediante aplicação de instrumento composto por questões abertas, sendo analisadas as percepções estudantis sobre duas questões: 1 . O que você entende por direitos humanos? 2. O que você entende por justiça?

PARA SUBSTITUIR... Na fase da pesquisa cujos dados são aqui apresentados houve a participação de 591 estudantes de $2^{\circ}$ e $6^{\circ}$ períodos de 15 cursos superiores ofertados por uma universidade do município de Curitiba.

Youth perceptions on human rights and justice were obtained through the participation of 591 students from $2^{\text {nd }}$ and $6^{\text {th }}$ periods of 15 under graduation courses offered by a university in the city of Curitiba. From the participants, $56.2 \%$ were in the $2^{\text {nd }}$ period of the courses and $43.8 \%$ in the $6^{\text {th }}$ period at the time of data collection.

\section{Diversity, Human Rights and Interculturality}

Listening to the subjects and analysis of contexts are required for the viability of more inclusive educational processes, evaluating "the degree of respect that the school curriculum and the life organization models in the school have with the different idiosyncrasies of groups and people who need to coexist in this institution” (Santomé, 2013: p. 225).

Therefore, knowing the traits of diversity at different levels, stages and types of education, can be a starting point. In this analysis, it is important to consider features related to aspects of race, ethnicity, gender, sexuality, generation, class, culture. From the study with students of higher education we bring sex, age and color declared by the students who participated in the survey. Regarding sex, among the participants there were $59.8 \%$ female and $39.9 \%$ male.

The age groups of students surveyed are distributed as follows: up to 18 years (19.2\%); 19 to 23 years (50.5\%); 24 to 28 years (17.2\%); 29 to 33 years (6.3\%). As for the ethnic group, the students declare themselves white (75.2\%); brown (14.6\%); black (3.3\%); yellow (1.1\%). 
There is a predominance of white youths in the range between 19 and 23 years, highlighting the ease of access of this population and the likely success of this school population in Basic Education, indicated by the age range considered suitable for entry into higher education. The participants' traces show they are from a privileged layer of the population, considering, for example, that according to data from the National Survey by Household (IBGE, 2011: p. 87), 48.2\% of the population are white, $44.2 \%$ mixed race and $6.9 \%$ black, and $0.7 \%$ have declared other colors. That is, the predominance of browns and blacks (51.1\%) representing the different ethnic groups and possibly linked to the poorest classes of the population is not manifested in the sample of this research, which shows the continued reproduction of social inequalities via education.

Thus, although they are very subtle traces of surveyed students' characterization are undeniably indicative of sustained exclusion and injustice, that is, the violation of the right to education to a big part of the population that does not reach higher education.

Access to higher education in Brazil occurs through entrance examinations, in other words, ranking examinations of high selectivity degree, which favor the population that has access to a basic education held in private schools, which emphasize more the preparation for tests. These populations also have the financial means to invest in pre-university courses. The limited number of vacancies in public institutions, in careers with a higher social status and more valued economically, associated with the way of selecting students unfeasible, therefore, the guarantee of the right to higher education to a part of the Brazilian youth who belong to economically disadvantaged classes and attended basic education in public schools.

In relation to the processes of inclusion/exclusion, Bauman (1998: p. 29) points out that two alternative and complementary strategies were intermittently developed, being possible to see that such strategies were and still are-adopted by educational institutions: the anthropoemic, which is regarded to the process of assimilation of the subjects, in other words, "make the different, similar"; and anthropophagic, which results in the exclusion itself, by means of segregation to other areas, or the simple expulsion of different, unequal.

Overcoming exclusion requires understanding and everyday political actions in which human rights, justice and intercultural education are closely linked and interdependent. Understanding and coexistence in this interrelation constitute challenges to be met, with a view to overcoming the denial and violation of rights and social injustices related to the recognition (identity/cultural), redistribution (economic) and representation (politics).

Although internationally recognized and guaranteed in laws, resolutions, declarations and conventions, the rights have not been guaranteed in their entirety. It is important to remember that "no law can, by itself, operate deep changes, no matter the advanced it is, nor to slow by itself the pace of progress of a given society, the more old-fashioned it is. Its application depends on a number of factors” (Romanelli, 1989: p. 33).

Many rights are not guaranteed, and others are still being violated in several nations, including Brazil. Bobbio (2004: p. 43) mentions that "the fundamental problem in relation to human rights today is not so much to justify them, but to protect them. This is a non-philosophical problem, but political".

Indeed, guarantee and protect the fundamental rights is a task that concerns everyone. The guarantee of human rights requires the recognition of what the rights are and understanding of their value as social transformer and builder of a more just and equalitarian society. The importance of the struggle to establish human rights in the consciousness of individuals and peoples is marked in Candau et al. (2013: p. 33) who points out that this action "must go through educational processes". In this context, education can exercise the primary function, promoting the opening for discussion, analysis and reflection of this issue and proposing specific actions for the protection and guarantee of rights in the educational space from the perspective of interculturality.

In this direction, in the survey performed with young students of higher education, it was asked them what they understand by human rights. Responses were grouped into categories that emerged from reading the set of participants' perceptions and are presented in Table 1.

Perceptions of $20.5 \%$ of students on human rights are related to the basic rights to survival and healthy life, from which we highlight the perceptions of the following students:

"They are the basic and essential points for the healthy survival of the human being, for example, sanitation, food, education, etc.” (Student n. 9).

"The basic survival items that every human being should have, such as security, education, shelter, health, basic sanitation" (Student n. 143).

Of the $13.2 \%$ of students who consider human rights as rights defined by law, by the "government", the following contributions are highlighted: 
Table 1. Participants’ perceptions on human rights.

\begin{tabular}{ccc}
\hline Categories-Variables & No. & \% \\
\hline Basic rights, essential to survival and healthy life. & 121 & 20.5 \\
Right which gives protection ensures individual and collective integrity. & 79 & 13.4 \\
Rights defined by law, by the "government". & 78 & 13.2 \\
Inherent right to human being. & 69 & 11.7 \\
Right as moral standardization, duty. & 49 & 8.3 \\
Rights which everyone can exercise-equality. & 48 & 3.1 \\
Right to choose, option, freedom. & 20 & 3.3 \\
Right as a guarantee of citizenship. & 96 & 16.1 \\
Diverse & $\mathbf{5 9 1}$ & $\mathbf{1 0 0}$ \\
Total & & 3.4 \\
\hline
\end{tabular}

Source: Data Bank of Violence Observatory in Schools from PUCPR.

"They are fundamental constitutionally protected rights such as the right of the guarantee of human dignity, health, education, ensuring social welfare and dignified living conditions" (Student n. 365).

"They are set of laws governing the state for the dignity of the human person, so that everyone, regardless of color, race, beliefs or sexuality can make enjoyment of legal rights that enable good sociability and respect to the human person. Among the rights we can list: housing, health, education, etc." (Student n. 441).

This trend in perceptions can be an indication of the effectiveness of the discourse on human rights as a progressive policy, but not necessarily as an emancipatory policy, in other words, the bias of this discourse is regulatory, not emancipatory. Such perceptions have their ingrained assumptions in the discourse, knowledge, processes and values of modernity which have shaped the concepts of human rights, according to (Santos, 1997, 2009; Candau, 2008). The statements of modernity bring difficulties and great complexity for the reinterpretation of human rights, in the establishment of an "intercultural conception of emancipating policies of human rights" (Candau, 2008: p. 54).

Intercultural conception assumes the knowledge of the other in their equality and difference. However, we can also observe in Table 1 analysis that despite the "right to choose, option, freedom" which indirectly includes the "right to be different", it was mentioned by $5.3 \%$ when referring to human rights, the necessary link between equality and difference does not appear in the students' responses.

The link between equality and difference requires as Candau (2008: p. 49) explains” [...] the passage of the statement of equality or difference to equality in difference. This is not to say equality, denying difference, not an absolute differentialist view that relativizes equality. The question is how to work the equality in difference. "Therefore, the author defends the intercultural perspective which "is oriented to the construction of a democratic, plural, human society, which links equality policies to identity policies” (Candau, 2008: p. 52).

In this sense, to build a social quality school is important to assume the intercultural perspective, because it is directed to: "the construction of a democratic, plural, human society, which links equality policies to identity policies” (Candau, 2008: p. 52). In this sense, we agree with Santos (1997: p 11) when he states that it is necessary "[...] to begin to understand the dialectical tension between social regulation and social emancipation which characterizes Western modernity—a well present tension in the philosophies and on human rights practices".

Thus, human rights consider equality, but also the differences are the challenges for a Human Rights Education in an intercultural perspective. Since, it is argued that "this is only possible if a policy of radically different human rights of the hegemonic liberal is adapted, and if such a policy is conceived as part of a broader constellation of struggles for social emancipation” (Santos, 2006: p. 433). Thus, the effectuation of the emancipatory potential of intercultural human rights cannot be thought a simplistic or linear way, or guided on the assumptions of modernity. We highlight the findings of Santos (2003, p. 21) that can help us in the desired direction.

We now live in obscenely unequal societies, and yet, equality is not imposed as an emancipatory ideal.

Equality, understood as equivalence between equals, ends up excluding what is different. All that is homo- 
geneous at the outset tends to turn into exclusionary violence. Hence the differences, carry with alternative views of social emancipation, must be respected. It is the duty of those who claim to decide to what extent whether to hybridize or undifferentiate. This relationship between the principle of equality and the principle of difference requires a new radicalism in the struggles for human rights.

There is much to be still achieved in terms of human rights guarantee, especially in dignity of the person in all his/her diversity and quality of life of many people regarding: education, health, housing, leisure, respect, life, family and community coexistence, freedom, sport, food, culture and professionalization. "The struggle for human rights should be seen as a powerful tool for social transformation, with the goal of building a fairer society and a tool to combat the exploitation of man by man” (Schilling, 2004: p. 12). In this struggle for human rights, it is necessary to exercise citizenship knowing your rights and demanding compliance, as advocated by Hannah Arendt (1978): "What remains unswerving, as a basic assumption, is the right to have rights".

Considering that the biggest part of the population lives in extreme poverty and does not have economic conditions to ensure the basic rights are necessary state actions to ensure the minimum of dignity through recognition of a better redistribution and representation, generating a more just and equalitarian society. In a society in which capitalism in its neoliberal version rules, the State's actions with these goals are characterized as compensatory policies, since they aim to mitigate inequalities without, however, changing socio-economic conditions through structural policies.

In this context, it is reinforced the need to fight for justice and equality through the guarantee of the right to intercultural education which, according to Candau (2008: p. 52), wants to promote "education for the recognition of the" other "for dialogue between different social and cultural groups". An education that is "able to promote the construction of a common project, by which the differences are dialectically integrated". In this process, it is important to promote participation and dialogue with students and young people, since they can contribute to transform the space in school of "[...] rights guarantee that dialogues with cultural diversity, including equality/difference of gender, race, ethnicity, sexual orientation and identity in curriculum practices” (Candau, 2008: p. 46).

\section{Justice and Intercultural Education}

If we long for a fairer society is necessary to develop actions to denounce and guarantee human rights, valuing the identity and uniqueness of every human being. Fraser (2008, p. 10) in his book "scales of justice" brings a thought-provoking question: What are the possible ways to practice justice in the age of globalization? Since there is no agreement on the subjects of justice (who is entitled, authorized to make claims) and on who should claim.

The central issue is to confront different views about who is the subject of justice: citizens or global humanity or transnational risk communities? (Fraser, 2008, p. 5). It is also important to establish the "what", the "who" and "how" of justice. According to Fraser (2008), the "what" of justice refers to the economic dimension, including the struggles for redistribution, the "cultural" dimension in struggles for recognition, and also the political dimension involved in the struggle for overcoming representation deficits. Regarding the "who" of justice Fraser (2008, p. 5) points to the "principle of all subjects" who should define the different milestones according to the different problems (local, national, regional or global). The "how" of justice should take place through a "democratic critical" approach using procedures to determine the "who" of justice. Thus, the "who" of justice (Fraser, 2008, p. 5) will only be respected in a democratic society where all human beings are worthy and have the same importance. So, they have equal rights and duties not only in economic, but also relating to all fundamental rights. "If justice concerns essences issues of equality, freedom and democracy, it turns out to be another name of education, a good education” (Estêvão, 2004: p. 96).

An education that sees the learner as citizen of rights, which sees recognized his/her citizenship and is empowered in terms of drilling of his/her rights. It is now a learner understood in all his/her dimensions, which implies a vision of education committed also to social justice, with the recognition of the other, with the power and autonomy (Estêvão, 2013: p. 32).

Still in relation to the interdependence between justice and appreciation of singularities, of respect and recognition of diversity, Santos (2007: p. 40) argues that "there is no global social justice without global cognitive justice or without justice among knowledge”. 
The inter relationship between the issues of human rights and justice is evident in that the students position themselves in relation to justice, specifically with regard to the idea of "equality" as shown in Table 2.

If we analyze the students' perceptions on Justice and Human Rights regarding "equality" we observe that: $17.5 \%$ of students relate justice to equal treatment, equality, while $8.1 \%$ think human rights as rights which everyone can exercise-equality. As illustrated by the data presented in Chart 1.

In the student's perceptions equality is a way to ensure justice and when this does not occur there is a violation of human rights, according to Arendt (1978: p. 387) "equality is not given, but the result of human organization and therefore is guided by the principle of justice 'the author also states that' we are not born equal; we become equal as members of a group by virtue of our decision for us to ensure the mutually equal rights".

For all people to have equal rights-there is included the right to difference-in fact it is necessary that the society is organized in such a way to guarantee the three pillars of justice appointed by Fraser: redistribution, recognition and representation, being redistribution the search for fairer allocation of resources and goods, "redistribute wealth from rich to poor, from North to South, and from the owners to the workers” (Fraser, 2007: p. 102), still according to the author: "The material inequality is high in most countries of the world [...] It also increases globally, more dramatically, across the dividing line between north and south” (Fraser, 2006: p. 231).

The recognition assumes that mobilized groups under the nation's flag of ethnicity, "race", gender and sexuality fight for "their differences to be recognized" (Fraser, 2006: p. 231). According to the author "The non-recognition consequently does not mean the depreciation and deformation of group identity. On the opposite, it means social subordination in the sense of being deprived to participate as an equal in social life" (Fraser, 2007: p. 107).

Regarding political representation, Fraser argues that justice requires social arrangements that permit all to participate as peers in social life. Overcoming injustice means overthrow institutionalized obstacles that prevent

Table 2. Students' perceptions on justice.

\begin{tabular}{|c|c|c|}
\hline Categories-Variables & $\mathbf{N}^{0}$. & $\%$ \\
\hline Equal treatment, equality & 89 & 17.58 \\
\hline Law enforcement, legal norms. & 69 & 13.6 \\
\hline Right and wrong standard application, "truth”. & 65 & 12.9 \\
\hline Access and guarantee of rights. & 62 & 12.3 \\
\hline Judgement, punishment or reward. & 50 & 9.9 \\
\hline Balance, impartiality in the trial. & 30 & 5.9 \\
\hline Solution compatible with the fact. & 20 & 4.0 \\
\hline Discernment, judicious decision. & 20 & 4.0 \\
\hline Diverse & 101 & 20.0 \\
\hline Total & 506 & 100 \\
\hline
\end{tabular}

Source: Data Bank of Violence Observatory in Schools from PUCPR.

\begin{tabular}{|c|c|}
\hline PERCEPTIONS ON JUSTICE & PERCEPTIONS ON HUMAN RIGHTS \\
\hline $\begin{array}{l}\text { "Justice is to do things in a way that is equal to all regardless of } \\
\text { class, ethnicity" (Student 34). } \\
\text { "Justice is a means of ensuring equality among human } \\
\text { beings, it is a matter of human rights" (Student 321). } \\
\text { "For me justice and equality are very approximate terms. I do } \\
\text { not think that there can be justice where differentiation among } \\
\text { men occurs. Justice would then be the application of a general } \\
\text { order in which all who are in a position of equal consciousness } \\
\text { must be gifted or punished hav ing as basis a unique } \\
\text { determination and without varying interpretations"(Student } \\
482 \text { ). }\end{array}$ & $\begin{array}{l}\text { "It is all have equal treatment, opportunities, regardless of } \\
\text { color, race, religion or social status" (Student 96) } \\
\text { "Equality for people regardless of race, color, sex, ethnicity, and } \\
\text { religion" (Student 331) } \\
\text { "They are rights and basic freed oms of all human beings as an } \\
\text { expression of thoughts and ideas, equality before the law (Student } \\
531 \text { ). } \\
\text { "Equality between people, we are all equal before the society, however } \\
\text { in practice this does not happen. There is a distinction between people } \\
\text { and a great social inequality among us" (Student 540). }\end{array}$ \\
\hline
\end{tabular}

Chart 1. The category equality on youth perceptions on justice and human rights. Source: Data Bank of Violence Observatory in Schools from PUCPR. 
some individuals to participate in equal conditions with others, as full partners in social interaction. (Fraser, 2008, p. 5).

The portion of exclusion of the population in political representation extends to the school environment. Dubet (2004: p. 552) calls attention to the care of the individuals' devaluation because "[...] there is an even greater injustice when the reproduction of inequalities comes with a stigma and a devaluation of individuals". The author also highlights the cruelty of these injustices: "It is both useless and cruel, it is an injustice done to the weaker students, the losers in the school competition. It is hard to fail and be driven to the undervalued jobs, but useful, it is cruel to be despised during this route".

In this sense, it is important to analyze the curricula being developed in schools, evaluating "the degree of respect that the school curriculum and organizational models of school life have with the different idiosyncrasies of groups and people who have to coexist in this institution” (Santomé, 2013: p. 225).

Social quality education implies a critical look, intended to be aware of the varied and multiple exclusions and discrimination present in the school curriculum, seeking to overcome them. Thus, we aim to wish this utopia regarding the students' emancipation to participate in the necessary changes for a fair and equalitarian society.

School can direct in this perspective, seeking knowledge and dialogue with the students' realities, considering equality, respecting differences and promoting human rights education, based on justice. Thus, the school, according to Candau (2000: p. 16) "enhances a questioning attitude, reveals the need to introduce changes in both the explicit curriculum, as the hidden curriculum, thus affecting the school culture and the culture of the school”. These changes are assumptions that we long for, perhaps to become the results of an intercultural perspective of education in human rights, which establish "links between equality and difference, that is, the passage of the statement of equality or difference to equality in difference" (Candau, 2008: p. 49). We reaffirm the need to be engaged in utopia as Benevides encourages us:

In a country like ours, marked by inequalities and injustices devastating, we cannot succumb to skepticism or melancholy of conformists. It is necessary to have a pedagogy of indignation-but free of resentment, which only cause sterile bitterness; It must have, as shown by Paulo Freire, a pedagogy of construction, awe and wonder at all that affirms life, which is a standing invitation to share the joy of living (Benevides, 2000: p. 349).

Moreover, a pedagogy that makes it possible to experience the maximum living of Santos (1997: p. 122) when he says that "we have the right to be equal when our difference makes us inferior, and we have the right to be different when our equality mischaracterizes us".

\section{Final Considerations}

The survey results and the ponderations discussed in the text challenge the implementation of public policies, especially educational policies that are founded on current claims for redistribution and recognition, ensuring equal access and respect for socio-cultural diversity of people.

Students' perceptions also point to the need for the school to be truly a space of guarantee and protection of rights, and thus of social justice promotion. This way, it will be possible a social quality basic education.

Such challenge can be taken from the intercultural perspective in order to work the "equality in difference", thus ensuring the rights and promoting social justice. Therefore, it not only summarizes the guarantee of basic rights and positivized nor the guarantee of an illusory "equal treatment/equity", or the application of laws/decontextualized and vertical legal rules. It is building an educational project that is emancipatory comprising " [....] a learning project of conflicting knowledge in order to, through it, producing radical and destabilizing images of social conflicts that have resulted in the past, images capable of enhancing the indignation and rebellion. Education, in this sense, for nonconformity.” (Santos, 1996: p. 17).

Thus, a school which aims to ensure social quality education to their collective considers three key points:

1) The curriculum as a privileged space for the establishment of intercultural dialogue on issues of democratic experience, including in this dialogue, the appreciation of the recognition of the other in all its social and cultural diversity.

2) Development of analysis processes and intercultural translation in order to expand knowledge and awareness of the power relations and colonialism, with a view to emancipation.

3) Experience and promotion of human rights and justice. 
Still, it will be necessary to face many challenges to the practice of these three aspects, considering the need to break the culture historically constructed of authoritarian practices, competitive, the inequalities of access, the injustices and rights violations. Justice in guaranteeing rights at school presupposes democratic experiences, fairness, respect for diversity, aiming at the students' empowerment through intercultural dialogue.

Hence the need for collective participation of the school community in the analysis, development and above all the experience of an intercultural curriculum can able to facilitate education in human rights in a fair and social quality school. The curriculum can be a privileged space for the establishment of dialogue on issues relating to democratic principles, to the experience of rights and justice.

\section{References}

Arendt, H. (1978). O Sistema Totalitário. (The Totalitarian System) Tradução de Roberto Raposo (Translation of Roberto Raposo). Lisboa: Publicações Dom Quixote.

Ball, S. J., \& Mainardes, J. (2011). Políticas Educacionais: Questões e Dilemas. (Educational Policies: Questions and Dilemmas). São Paulo, SP: Editora Cortez.

Bardin, L. (2000). Análise de conteúdo (Content analysis). Tradução de Luis Antero Reto e Augusto Pinheiro (Translation of Luis Antero Reto and Augusto Pinheiro). Lisboa: Edições 70.

Bauman, Z. (1998). O mal-estar da pós-modernidade (Postmodernity Malaise). Rio de Janeiro, RJ: Jorge Zahar Ed.

Benevides, M. V. (2000). Educação em direitos humanos: De que se trata? (Human Rights Education: What Is It About?). Palestra de abertura do Seminário de Educação em Direitos Humanos (Opening lecture of the Seminar of Human Rights Education), São Paulo, SP.

Bobbio, N. (2004). A era dos direitos (The era of rights). Tradução de Carlos Nelson Coutinho, apresentação de Celso Lafer

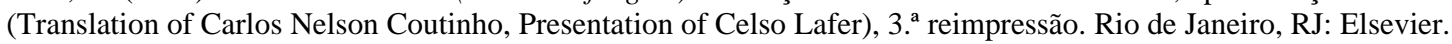

Boneti. L. W. (2011). Políticas Públicas Por Dentro. (Public Policies Inside) (3th ed.). Ijuí, RS: Editora Unijuí.

Candau, V. M. (2000). Educação em direitos humanos no Brasil: realidade e perspectiva (Human Rights Education in Brazil: reality and perspective). In V. M. Candau, \& S. Sacavino (Eds.), Educação e direitos humanos: construir a democracia (Education and Human Rights: To Build Democracy) (p. 72-99). Rio de Janeiro, RJ: DP \& A.

Candau, V. M. (2008). Direitos humanos, educação e interculturalidade: As tensões entre igualdade e diferença (Human Rights, Education and Interculturality: Tensions between Equality and Difference). Revista Brasileira de Educação, 13, 45-56.

Candau, V. M., Paulo, I., Andrade, M., Lucinda, M. da C., Sacavino, S., \& Amorim, V. (2013). Educação em Direitos Humanos e Formação de Professores (as) (Human Rights Education and Teacher's Education). São Paulo, SP: Cortez.

Dubet, F. (2004). O que é uma escola justa? (What Is a Fair School?) Cadernos de Pesquisa, 34, 539-555. http://dx.doi.org/10.1590/S0100-15742004000300002

Dubet, F. (2008). O que é uma escola justa?: A escola das oportunidades. (What Is a Fair School? The School of Oportunities). São Paulo, SP: Cortez.

Estêvão, C. V. (2004). Educação, justiça e democracia: Um estudo sobre as geografias da justiça em educação [Education, Justice and Democracy: A Study on Geography of Justice on Education]. São Paulo: Cortez.

Estêvão, C. V. (2013). Democracia política, democracia escolar e educação para os direitos humanos [Political Democracy, School Democracy and Education for Human Rights]. Educação, 36, 28-34.

Eyng, A. M. (2013). Educação em Direitos humanos no currículo escolar: O projeto político pedagógico como espaço de garantia ou violação de direitos [Education on Human Rights in the School Curriculum: The Political Pedagogical Project as Space of Guarantee or Violation of Rights]. In A. M. Eyng (Org.). Direitos humanos e violências nas escolas: Desafios e questões em diálogo [Human Rights and Violence in Schools: Challenges and Issues in Dialogue] (pp. 29-58). Curitiba: CRV.

Fraser, N. (2006). Da redistribuição ao reconhecimento? Dilemas da justiça na era pós-socialista [From Redistribution to Recognition? Dilemmas of Justice in Post-Socialist Era]. Tradução: Julio Assis Simões (Translation of Julio Assis Simões). Cadernos de Campo, 14/15, 1-382.

Fraser, N. (2007). Reconhecimento sem ética? Lua Nova: Revista de Cultura e Política, 70, 101-138. http://dx.doi.org/10.1590/S0102-64452007000100006

Gomes, C. A. (2005). A Escola de Qualidade para Todos: Abrindo as Camadas da Cebola [The Quality School for All: Opening the Onion Layers]. Avaliação e Políticas Públicas em Educação, 13, 281-306.

Instituto Brasileiro de Geografia e Estatística (IBGE) (2011). Pesquisa Nacional por amostra de domicílios: Síntese dos indicadores [National Survey sample Households: Summary of Indicators]. 
http://www.ibge.gov.br/home/estatistica/populacao/trabalhoerendimento/pnad2011/

Organização das Nações Unidas (ONU) (1948). A Declaração Universal dos Direitos Humanos [A Universal Declaration of Human Rights]. http://www.dhnet.org.br/direitos/deconu/a_pdf/comparato_hist_dudh.pdf

Romanelli, O. O. (1989). História da educação no Brasil (1930/1973) [History of education in Brazil (1930/1973)] (11th ed.). Petrópolis: Editora Vozes.

Santomé, J. T. (2013). Currículo escolar e justiça social: O cavalo de Troia da educação [School Curriculum and Social Justice: The Education Trojan Horse]. Porto Alegre: Penso.

Santos, B. S. (1997). Por uma concepção multicultural de direitos humanos [For a Multicultural Conception of Human Rights]. Revista Crítica de Ciência Sociais, 48, 11-32.

http://www.boaventuradesousasantos.pt/media/pdfs/Concepcao multicultural direitos humanos RCCS48.PDF

Santos, B. S. (2006). A gramática do tempo: Para uma nova cultura política [The Grammar of the Time: For a New Political Culture]. São Paulo: Cortez.

Santos, B. S. (1996). Para uma pedagogia do conflito [For a Pedagogy of Conflict]. In L.H. Silva et al. (Eds.), Novos mapas culturais: Novas perspectivas educacionais. Porto Alegre: Sulina.

Santos, B. S. (2007). Renovar a teoria crítica e reinventar a emancipação social [Renew Critical Theory and Reinvent Social Emancipation). São Paulo: Boitempo Editorial.

Schilling, F. (Ed.) (2004). Direitos Humanos e Educação: Outras palavras, outras práticas [Human Rights and Education: Other Words, Other Practices]. São Paulo: Editora Cortez.

Shiroma, E. O., Moraes, M. C. M., \& Evangelista, O. (2002). Política Educacional [Educational Policy]. Rio de Janeiro: DP \& A.

Silva, M. A. (2009). Qualidade Social da Educação Pública: Algumas Aproximações (Social Quality of Public Education: Some approaches). Cadernos Cedes, 29, 216-226. http://www.cedes.unicamp.br 